\title{
Hubungan Kecerdasan Emosional Dengan Hasil Belajar IPA Siswa SMP Negeri 1 Palu
}

\author{
Defila, Muslimin, dan Sahrul Saehana \\ email: oel_281@yahoo.com \\ Program Studi Pendidikan Fisika, Jurusan Pendidikan MIPA, Universitas Tadulako \\ Jl. Soekarno Hatta KM.9, Kampus Bumi Tadulako Tondo Palu - Sulawesi Tengah
}

\begin{abstract}
Abstrak- Tujuan penelitian ini yaitu untuk mengetahui hubungan kecerdasan emsional dengan hasil belajar IPA. Populasi penelitian ini yaitu seluruh siswa kelas VIII SMP Negeri 1 Palu. Sampel penelitian ini adalah siswa kelas VIII A dan kelas VIII H SMP Negeri 1 Palu. Sampel diambil secara acak dengan menggunakan teknik simple random sampling. Dimana sampel penelitian ini terdiri dari 43 orang. Kelas yang menjadi sampel penelitian diberikan tes kecerdasan emosional berupa angket. Data kecerdasan emosional diperoleh dari angket siswa, sedangkan nilai hasil belajar diperoleh dari data rapor siswa, kemudian dikorelasikan dengan nilai tes kecerdasan emosional. Dalam pengujian hipotesis dengan menggunakan uji korelasi product moment diperoleh $\mathrm{r}_{\text {hitung }}=0,559$ dan $r_{\text {tabel }}=0,301$ pada $a=0,05$. Presentase pengujian hipotesis diperoleh hasil sebesar $31,25 \%$ pengaruh kecerdasan emosional terhadap hasil belajar IPA. Berdasarkan hasil yang diperoleh, disimpulkan bahwa terdapat hubungan antara kecerdasan emosional dengan hasil belajar IPA.
\end{abstract}

Kata Kunci: Kecerdasan emosional dan hasil belajar

\section{PENDAHULUAN}

Undang-Undang Nomor 20 tahun 2003 tentang Sistem Pendidikan Nasional pasal 3 menjelaskan fungsi Pendidikan nasional adalah mengembangkan kemampuan dan membentuk watak serta peradaban bangsa yang bermartabat dalam rangka mencerdaskan kehidupan bangsa; dan tujuan pendidikan nasional untuk mengembangkan potensi peserta didik agar menjadi manusia yang beriman dan bertakwa kepada Tuhan Yang Maha Esa, berakhlak mulia, sehat, berilmu, cakap, kreatif, mandiri, dan menjadi warga negara yang demokratis serta bertanggung jawab [1]. Implikasi dari UndangUndang tersebut bahwa, pendidikan di setiap jenjang, termasuk Sekolah Menengah Atas (SMA) harus diselenggarakan secara terprogram dan sistematis mengarah kepada pencapaian tujuan pendidikan nasional.

Selanjutnya yaitu pada Undang-Undang Bab II Pasal 3 No. 20 Tahun 2003 tentang Sistem Pendidikan Nasional yang mana pendidikan bertujuan mengembangkan potensi peserta didik agar menjadi manusia yang beriman dan bertakwa kepada Tuhan Yang Maha Esa, berakhlak mulia, sehat, berilmu, cakap, kreatif, mandiri, dan menjadi warga negara yang demokratis serta bertanggung jawab. Kemudian Pasal 1 UU Sisdiknas tahun 2003 menyatakan di antara tujuan pendidikan nasional adalah mengembangkan potensi peserta didik untuk memiliki kecerdasan, kepribadian, dan akhlak mulia. Berangkat dari undang-undang ini, dapat kita temukan bahwa garis besar dari tujuan pendidikan nasional adalah selain mencerdaskan peserta didik, juga terciptanya karakter peserta didik yang beriman, mandiri, dan berahklak mulia. Bila demikian, dengan melihat potretpotret dunia pendidikan saat ini, bisa dikatakan sistem pendidikan nasional sudah gagal memenuhi tujuan undang-undang tersebut [1].

Hasil penelitian Daniel Goleman dan beberapa riset di Amerika [2] memperlihatkan bahwa kecerdasan intelektual hanya memberi konstribusi $20 \%$ terhadap kesuksesan hidup seseorang. Sisanya $80 \%$ bergantung pada kecerdasan emosi, kecerdasan social, dan kecerdasan spritualnya. Bahkan dalam keberhasilan kerja, kecerdasan intelektual hanya berkontribusi 4\%. Salovey dan Meyer 
melaporkan bahwa kecerdasan emosi mengacu pada kemampuan mengendalikan emosi Anda dan orang lain untuk membedakan antara mereka dan memanfaatkan informasi untuk mengarahkan individu atau kinerja [3].

Mark Davis dalam bukunya "Tes EQ Anda", Dia mengutip Penelitian Marshmallow, dimana seorang penguji menaruh dua Marshmallow (permen) di meja dan mengatakan pada anak 4 tahun dia memiliki pilihan: "Dia boleh memakan sebuah sekarang atau makan dua-duanya nanti". Sesaat setelah penguji kembali lagi. Kemudian anak itu ditinggal sendiri. Sepertiga dari anakanak itu mengambil marshmallow dan memakannya. Yang lain melakukan segala macam kegiatan untuk menahan godaan, dari menutup mata sampai bernyanyi. Selanjutnya anak yang sama diteliti sampai sekolah tinggi. Ada perbedaan yang cukup mencolok diantara mereka. Anak yang langsung memakan marshmallow telah menjadi anak remaja yang bimbang, seringkali frustasi, dan tidak tahan banting. Anak yang dapat menunda kepuasan mampu mengatasi rasa frustasi, mandiri dan tabah. Yang lebih mengejutkan adalah nilai SATnya: Anak yang "langsung memakan" nilai rataratanya dalam bahasa dan matematika 100 angka dibawah yang dapat menunda kepuasan [4].

Menurut Lickona [5], karakter berkaitan dengan konsep moral (moral knonwing), sikap moral (moral felling), dan perilaku moral (moral behavior). Berdasarkan ketiga komponen ini dapat dinyatakan bahwa karakter yang baik didukung oleh pengetahuan tentang kebaikan, keinginan untuk berbuat baik, dan melakukan perbuatan kebaikan. Hal ini juga sejalan dengan tujuan pendidikan nasional yaitu selain mencerdaskan peserta didik, juga terciptanya karakter peserta didik yang beriman, mandiri, dan berakhlak mulia.

Kecerdasan emosional diperlukan apabila individu menghadapi masalah yang dapat menimbulkan tekanan untuk individu tersebut sehingga dapat mengendalikan emosi yang dimilikinya agar dapat menghadapi masalah dengan baik [6]. Ketatnya persaingan dibidang
ISSN 23383240

pendidikan, membuat sebagian besar siswa menempuh segala macam cara untuk dapat bersaing pada keadaan tersebut. Misalnya dengan mengikuti pelajaran tambahan baik itu privat maupun les yang diadakan oleh pihak sekolah. Hal tersebut bertujuan untuk menambah pengetahuan intelektual siswa. Padahal kemampuan intelektual saja tidak cukup untuk mengikuti persaingan tersebut. Tetapi dengan kemampuan mengelola emosi, individu akan mampu mengelola emosinya dan mampu memahami orang lain. Dengan begitu, individu akan mampu bersaing dan kemampuan intelektual yang ia miliki akan semakin berkembang. Sebaliknya individu yang tidak mampu mengelola emosi dirinya dan tidak mampu memahami orang lain, dengan sendirinya ia akan merasakan tekanan, akan mudah putus asa, menjadi pribadi yang tidak percaya diri, sehingga kemampuannya tidak akan berkembang.

Beberapa penelitian menunjukkan pentingnya seseorang memiliki kecerdasan emosional. Hasil penelitian Gottman [6] menunjukkan fakta bahwa pentingnya kecerdasan emosional dalam berbagai aspek kehidupan. Dengan mengaplikasikan kecerdasan emosional dalam kehidupan akan berdampak positif baik dalam kesehatan fisik, keberhasilan akademis, kemudahan dalam membina hubungan dengan orang lain, dan meningkatkan resilensi.

Dari uraian di atas, penulis menyimpulkan bahwa terdapat hubungan antara kecerdasan emosional terhadap keberhasilan individu dalam hal ini keberhasilan akademis sehingga penulis akan mengadakan penelitian untuk melihat hubungan antara kecerdasan emosional dengan hasil belajar IPA siswa.

\section{METODELOGI PENELITIAN}

Jenis penelitian ini adalah kuantitatif assosiatif. Populasi dalam penelitian ini adalah seluruh siswa kelas VIII SMP Negeri 1 Palu yang terdiri dari 9 kelas tahun ajaran 2013/2014.

Pengambilan sampel pada penelitian ini adalah simple random sampling, yaitu teknik penentuan 
sampel yang dilakukan secara acak tanpa memperhatikan strata yang ada dalam populasi tersebut. [7]

Data yang diambil dari penelitian ini yaitu nilai kecerdasan emosional siswa dan hasil belajar siswa kemudian dianalisis dengan menggunakan uji hipotesis korelasional product moment. Desain penelitian yang digunakan seperti pada Gambar 1.

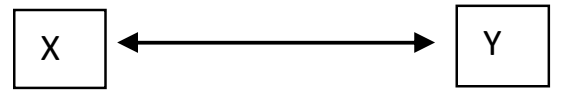

Gambar 1 Desain penelitian asosiatif

Keterangan:

$X$ : kecerdasan emosional

Y: Hasil belajar

\section{HASIL DAN PEMBAHASAN}

Pengujian hipotesis menggunakan uji korelasi product moment yaitu untuk mengetahui bagaimana hubungan antara kecerdasan emosional dengan hasil belajar IPA. Syarat uji korelasi [8] yaitu data acak, data homegen, terdistribusi normal dan linear. Pada penelitian ini, data dianalisis dengan menggunakan program SPSS (Statical Product and Service Solution) versi 18.0

Sebelum memilih sampel, terlebih dahulu dilakukan uji homogenitas populasi untuk menentukan apakah sampel dalam popolasi yang homogen agar bisa diambil secara acak. Hasil yang diperoleh yaitu $X^{2}$ hitung $=21,60$ dan $X^{2}$ Tabel $(\mathrm{dk}=8, \mathrm{a}=0,005)=22,00$. Syarat penerimaan uji Barlet, jika $X^{2}$ hitung $<X^{2}$ Tabel maka data dinyatakan homogen tetapi jika $X^{2}$ hitung $>$ $\mathrm{X}^{2}$ Tabel maka data dinyatakan tidak homogen. Dari syarat tersebut dapat disimpulkan bahwa hasil pengujian data homogen.

Nilai kecerdasan emosional siswa diperoleh dari hasil tes kecerdasan emosional dan nilai hasil belajar diperoleh dari nilai raport siswa. Data dari kedua variabel dapat dilihat pada Tabel 1.
TABEL 1. Nilai Tes Kecerdasan Emosional Dan Hasil Belajar

\begin{tabular}{|c|c|c|}
\hline SISWA & $\begin{array}{c}\text { NILAI } \\
\text { KECERDASAN } \\
\text { EMOSIONAL }\end{array}$ & $\begin{array}{c}\text { NILAI } \\
\text { HASIL } \\
\text { BELAJAR }\end{array}$ \\
\hline$A Z$ & 74 & 88 \\
\hline RT & 56 & 80 \\
\hline YN & 66 & 82 \\
\hline IS & 62,67 & 82 \\
\hline $\mathrm{SH}$ & 65,33 & 82 \\
\hline DR & 73,33 & 86 \\
\hline DF & 56,67 & 81 \\
\hline RT & 72,67 & 83 \\
\hline FE & 68,67 & 83 \\
\hline $\mathrm{BL}$ & 69,33 & 88 \\
\hline WE & 68,67 & 84 \\
\hline YI & 68 & 83 \\
\hline $\mathrm{RE}$ & 60,67 & 80 \\
\hline NM & 62,67 & 83 \\
\hline MU & 77,33 & 83 \\
\hline GI & 72 & 86 \\
\hline $\mathrm{AH}$ & 68 & 85 \\
\hline$A B$ & 66 & 84 \\
\hline TI & 62,67 & 85 \\
\hline PR & 79,33 & 86 \\
\hline WN & 58,67 & 85 \\
\hline AA & 69,33 & 85 \\
\hline $\mathrm{MH}$ & 56 & 85 \\
\hline $\mathrm{KI}$ & 54,67 & 80 \\
\hline $\mathrm{KR}$ & 64,67 & 82 \\
\hline VR & 63,33 & 81 \\
\hline $\mathrm{ZN}$ & 68,67 & 85 \\
\hline $\mathrm{QR}$ & 66 & 84 \\
\hline ND & 69,33 & 83 \\
\hline $\mathrm{IL}$ & 62 & 88 \\
\hline TM & 68,67 & 85 \\
\hline $\mathrm{ZO}$ & 60 & 83 \\
\hline EN & 68,67 & 88 \\
\hline $\mathrm{AL}$ & 61,33 & 82 \\
\hline YY & 64,67 & 84 \\
\hline FS & 61,33 & 86 \\
\hline WR & 56 & 80 \\
\hline MY & 60,67 & 81 \\
\hline RO & 67,33 & 86 \\
\hline $\mathrm{LL}$ & 74 & 91 \\
\hline $\mathrm{HU}$ & 68 & 83 \\
\hline $\mathrm{JY}$ & 69,33 & 85 \\
\hline LS & 55,33 & 82 \\
\hline Rata-rata & 65,53512 & 83,90 \\
\hline
\end{tabular}

Setelah diperoleh data dari dua variabel, diuji normalitas kedua data. Dari hasil analisis diperoleh uji normalitas kecerdasan emosional dengan nilai signifikan $=0,402$ dan pada hasil belajar nilai signifikan $=0,087$. Berdasarkan syarat statistik uji normalitas, jika nilai 
signifikansi $>0,05$ maka data terdistribusi normal. Dari hasil yang diperoeleh, dapat disimpulkan kedua data terdistribusi normal.

Penentuan kedua variabel linear atau tidak, digunakan uji regresi linear. Hasil uji regresi antara dua variabel diperoleh nilai signifikansi = 0,001 . Berdasarkan syarat statistik uji $F$, jika nilai signifikansi $<0,05$ maka hubungan antara dua variabel linear dengan persamaan garis $Y=$ 0,2319x + 68,709. Dari hasil yang diperoleh, dapat disimpulkan kedua data linear. Grafik kelinearan kedua variabel dapat dilihat pada Gambar 2.

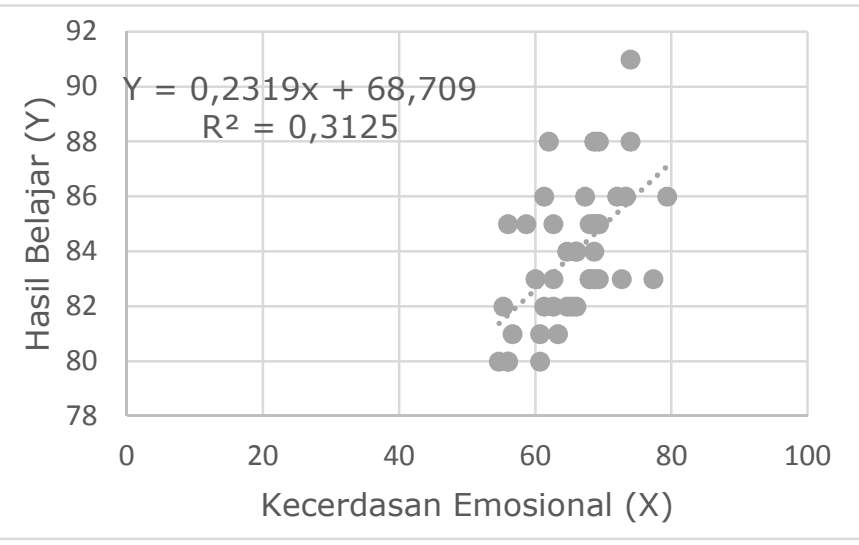

Gambar 2 Grafik Uji Regresi

Hasil uji hipotesis berdasarkan tabel nilai-nilai $r$ product moment, diperoleh nilai $r_{\text {tabel }}$ dengan jumlah sampel 43 pada $\alpha=0,05$ yaitu 0,301. Dari hasil analisis diperoleh $r_{\text {hitung }}=0,559>r_{\text {tabel }}=$ 0,301, maka dapat ditarik kesimpulan kedua variabel memiliki hubungan. Untuk mengetahui apakah nilai korelasi yang diperoleh berlaku untuk semua populasi maka digunakan uji $t$. Hasil yang diperoleh $t_{\text {hitung }}=4,28>t_{\text {hitung }}=$ 1,68 . Berdasarkan syarat penerimaan apabila $t_{\text {hitung }}>t_{\text {tabel }}$ maka terdapat hubungan yang signifikan. Hasil determinasi atau nilai kuantitatif pengaruh kecerdasan emosional dengan hasil belajar sebesar 31,25\%.

Diketahui jumlah sampel sebanyak 43 orang dan skor maksimum tiap soal bernilai 5 .
TABEL 2. Kecerdasan Emosional Per Aspek

\begin{tabular}{|c|c|c|c|c|c|c|}
\hline $\begin{array}{l}\mathrm{A} \\
\mathrm{s} \\
\mathrm{p} \\
\mathrm{e} \\
\mathrm{k}\end{array}$ & $\begin{array}{c}\text { Juml } \\
\text { ah } \\
\text { sisw } \\
\text { a x } \\
\text { skor } \\
\text { maks } \\
\text { imu } \\
\text { m } \\
\text { (a) }\end{array}$ & $\begin{array}{l}\text { Juml } \\
\text { ah } \\
\text { Soal } \\
\text { (b) }\end{array}$ & $\begin{array}{l}(a) \times(b \\
)\end{array}$ & $\begin{array}{l}\text { Total } \\
\text { Jawab } \\
\text { an (c) }\end{array}$ & $\begin{array}{c}\frac{(c)}{(a)(b)} \\
(\mathrm{d})\end{array}$ & $\begin{array}{c}\text { (d) } x \\
100 \\
\%\end{array}$ \\
\hline 1 & 215 & 9 & 1935 & 1182 & 0,61 & $61 \%$ \\
\hline 2 & 215 & 7 & 1505 & 994 & 0,66 & $66 \%$ \\
\hline 3 & 215 & 4 & 860 & 588 & 0,68 & $68 \%$ \\
\hline 4 & 215 & 4 & 860 & 633 & 0,74 & $74 \%$ \\
\hline 5 & 215 & 6 & 1290 & 830 & 0,64 & $64 \%$ \\
\hline
\end{tabular}

Dalam bentuk diagram dapat dilihat perbandingan kecerdasan emosional peraspek sebagai berikut

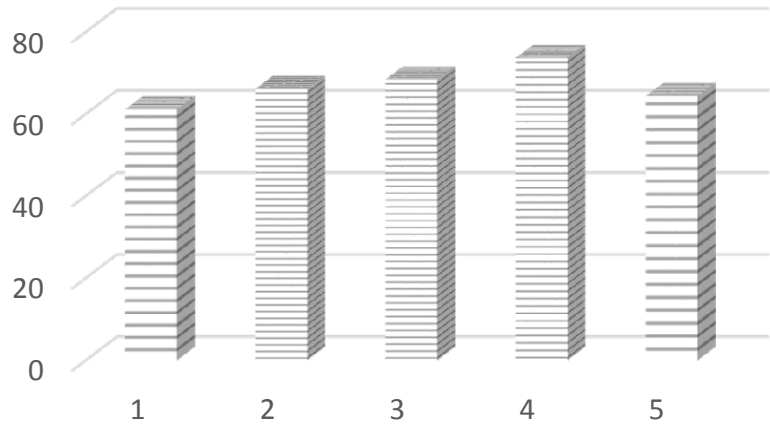

Gambar 3 Kecerdasan emosional per aspek

Keterangan :

1: aspek mengenal emosi diri

2: aspek mengelola emosi

3: aspek mengenal emosi orang lain

4: aspek empati

5: aspek membina hubungan

Penelitian ini merupakan penelitian korelasional antara kecerdasan emosional dengan hasil belajar siswa untuk melihat hubungan antara kedua variabel tersebut. Berdasarkan uji homogenitas penentuan sampel telah diperoleh hasil bahwa populasi pada keadaan homogen sehingga dapat diambil sampel secara acak. Menurut Rescoe [7], ukuran sampel dalam penelitian adalah antara 30 sampai dengan 500 . Sehingga pada penelitian ini 
digunakan dua kelas yaitu kelas VIII A dan VIII $H$ untuk memenuhi syarat ukuran sampel penelitian karena jumlah siswa setiap kelas kurang dari 30 siswa.

Kelas yang telah ditentukan sebagai sampel penelitian diberi tes kecerdasan emosional. Setelah itu untuk memperoleh nilai hasil belajar, peneliti menggunakan nilai rapor siswa. Alasan peneliti menggunakan nilai rapor karena merupakan nilai akhir dari suatu proses pembelajaran yang di dalamnya telah terdapat berbagai aspek-aspek penilaian selama proses pembelajaran.

Analisis hasil penelitian dilakukan dengan menggunakan program SPSS (Statical Product and Service Solution), meliputi uji normalitas, uji homogenitas, uji regresi, dan uji hipotesis korelasi. Dari hasil analisis pengujian hipotesis penelitian dengan menggunakan uji korelasi product moment pada sampel dengan jumlah 43 orang diperoleh hasil $r_{\text {hitung }} 0,559>$ $r_{\text {tabel }} 0,301$ dengan $\alpha=0,05$ yang berdasarkan kriteria penerimaan hipotesis jika $r_{\text {hitung }}>$ $r_{\text {tabel }}$ maka hipotesis diterima atau terdapat hubungan yang signifikan. Hasil tersebut berlaku untuk semua populasi yang berjumlah 246 siswa, hal ini didasarkan pada uji signifikansi yang diperoleh thitung $=4,28$ dan $t_{\text {tabel }}=1,68$. Berdasarkan kriteria penerimaan hasil $u j i$ signifikansi thitung $>t_{\text {tabel }}$ berarti hubungannya signifikan.

Berdasarkan hasil yang diperoleh, hal ini sejalan dengan penelitian-penelitian sebelumnya bahwa terdapat hubungan antara kecerdasan emosional dengan hasil belajar siswa. Nurfidyatin [9] dalam penelitiannya menyatakan dari hasil perhitungan korelasi pada penelitian ini dengan menggunakan prodect moment didapatkan hasil 0,735 artinya kedua variabel memiliki hubungan yang erat. Setyowati [6] juga manyatakan bahwa dengan mengaplikasikan kecerdasan emosional dalam kehidupan akan berdampak positif baik dalam kesehatan fisik, keberhasilan akademis, kemudahan dalam membina hubungan dengan orang lain, dan meningkatkan resilensi. Dari hasil penelitiannya, Setyowati memperoleh nilai kontribusi kecerdasan emosional sebesar 64,11\%.

Hasil pengujian hipotesis pada penelitian ini jika dipresentasekan diperoleh nilai sebesar $31,25 \%$. Hasil tersebut dikategorikan sedang berdasarkan Tabel 3.3. Tidak seperti pada penelitian Setyowati dan Nurfidyatin yang memperoleh hasil dalam kategori kuat. Kategori sedang yang diperoleh mungkin disebabkan karena pada saat melakukan tes kecerdasan emosional, sebagian siswa merasakan tekanan terhadap tes kemampuan diri yang diberikan karena cenderung siswa masih canggung mengisi walaupun pada saat sebelum siswa mengisi tes kecerdasan emosional, peneliti melakukan beberapa pendekatan sehingga tetap diperoleh hubungan antara kecerdasan emosional dengan hasil belajar walaupun masih dalam kategori sedang seperti pada penelitianpenelitian sebelumnya.

Sebuah laporan dari National Center for Clinical Infant Programs [10] menyatakan bahwa keberhasilan di sekolah bukan diramalkan oleh kumpulan fakta seorang siswa atau kemampuannya dininya untuk membaca, melainkan oleh ukuran-ukuran emosional dan sosial, yakni pada diri sendiri dan mempunyai minat, tahu pola pikir yang diharapkan orang lain dan bagaimana mengendalikan dorongan hati untuk berbuat bakal, mampu menunggu, mengikuti petunjuk dan mengacu pada guru untuk mencari bantuan, serta mengungkapkan kebutuhan-kebutuhan saat bergaul dengan siswa lain. Sehingga pada penelitian ini, peneliti melihat hubungan kecerdasan emosional siswa dengan hasil belajar IPA dari nilai rapor, karena hal ini terkait dengan hasil akhir dari proses pembelajaran yang di dalamnya terdapat tiga pokok penilaian yaitu kognitif, afektif, dan psikomotor. Ranah kognitif mencakup kemampuan pengetahuan, pemahaman, penerapan, analisis, sintesis, dan evaluasi dari setiap siswa. Ranah psikomotor mencakup keterampilan atau kemampuan bertindak setelah menerima pelajaran. Ranah afektif mencakup nilai sikap, emosi, dan watak. Apabila siswa telah mampu memenuhi ketiga ranah penilaian 
tersebut maka siswa cenderung mendapat nilai yang tinggi.

Melihat dari aspek-aspek yang terkandung dalam tiga ranah penilaian, sehingga dapat dikatakan bahwa siswa yang pintar atau yang memiliki nilai yang tinggi di sekolahnya juga memilki kecerdasan emosional yang baik karena ketiga ranah tersebut telah mencakup kemampuan kognitif, kemampuan mengelola sikap, dan kemampuan bertindak atau keterampilan. Siswa yang mendapat nilai yang tinggi atau dengan kata lain siswa yang pintar cenderung baik dalam mengelola emosinya. Mereka umumnya lebih empatik, lebih jarang membolos, sedikit saja atau sama sekali tidak merokok, dan mereka lebih memikirkan baikbaik untuk melakukan tindakan yang merugikan [11]. Pernyataan ini didukung dengan hasil penelitian yang diperoleh kelinearan antara dua variabel berdasarkan perhitungan pada Lampiran 6 atau yang terdapat pada Gambar 1, sehingga bisa terlihat bahwa semakin tinggi kecerdasan emosional siswa maka semakin tinggi pula hasil belajarnya.

Pada Gambar 1 dapat dilihat hubungan variabel $X$ dan $Y$ dalam bentuk diagram pencar. Diagram pencarnya menunjukkan hubungan garis positif tapi lebih tersebar, untuk mengetahui persamaan garis lurus yang terbentuk dari Gambar 1 digunakan persamaan regresi. Tujuannya adalah untuk melihat seberapa besar pengaruh variabel $X$ terhadap $Y$ dan dapat meramalkan nilai $Y$ jika variabel $X$ yang berkorelasi dengan $Y$ nilainya sudah diketahui [12]. Interprestasi dari persamaan regresi yang diperoleh $Y=0,2319 x+68,709$ yaitu ketika nilai $X$ (kecerdasan emosional) bertambah satu, maka nilai Y (hasil belajar) akan naik sebesar 0,2319. Nilai $R$ square atau nilai determinasi menunjukkan pengaruh kecerdasan emosional sebesar 0,3125 dalam persen sama dengan $31,25 \%$ terhadap hasil belajar. Sisanya dipengaruhi oleh faktor-faktor lain yang tidak diikutkan pada analisis penelitian ini atau tidak dalam variabel penelitian. Faktor-faktor tersebut dapat berupa pengaruh pola asuh orang tua, interaksi teman sebaya [13], kinerja mengajar guru, dan pemanfaatan fasilitas belajar [14]juga memberikan pengaruh terhadap hasil belajar. Pada Tabel 2 untuk aspek mengenal emosi diri, diperoleh hasil $61 \%$, untuk aspek mengelola emosi diri diperoleh hasil 66\%, untuk aspek memahami emosi orang lain diperoleh hasil $68 \%$, untuk aspek empati diperoleh hasil $74 \%$, dan untuk aspek membina hubungan diperoleh hasil 64\%. Dari kelima aspek kecerdasan emosional dapat dilihat aspek empati lebih tinggi dari aspek-aspek yang lain.

Perlu diketahui karakter itu bisa dirubah melalui pengelolaan kemampuan emosi diri. Kecerdasan emosi yang baik berkaitan dengan kualitas karakter seseorang. Sehingga sekarang ini diterapkan pendidikan yang berkarakter untuk menghasilkan peserta didik selain cerdas juga terciptanya karakter peserta didik yang beriman, mandiri, dan berahklak mulia. Seperti yang diungkapkan oleh Ki Hajar Dewantara bahwa "karakter itu terjadi karena perkembangan dasar yang sudah terkena pengaruh ajar" [11].

\section{KESIMPULAN DAN SARAN}

Berdasarkan hasil penelitian dan analisis data hasil penelitian, maka dapat disimpulkan bahwa terdapat hubungan antara kecerdasan emosioanl dengan hasil belajar IPA siswa SMP negeri 1 Palu. Hal ini dibuktikan dengan hasil uji hipotesis dimana nilai $r_{\text {hitung }}=0,559>r_{\text {tabel }}=0,301$ artinya $\mathrm{H}_{1}$ diterima dan $\mathrm{H}_{0}$ ditolak. Dengan pengaruh presentase sebesar $31,25 \%$ dalam kategori sedang. Presentase ini mungkin dapat meningkat jika pelaksanaan tes kemempuan diri (tes kecerdasan emosional) didasarkan pada kaidah yang sebenarnya. 


\section{DAFTAR PUSTAKA}

[1]Direktorat Jurnal Pendidikan Dasar, Kemdiknas. 2004. Pendidikan Karakter untuk membangun Karakter Bangsa. Jakarta: Direktorat Jendral Pendidikan Dasar.

[2]Rachmi, F. 2010. Pengaruh Kecerdasan Emosional, Kecerdasan Spritual, dan Perilaku Belajar terhadap Pemahaman Akuntansi. Semarang: UNDIP.

[3] Najafi, M. 2012. Studying the Effect of Emotional Quotient on Employee's Job Satisfaction (The case of Isfahan University of Medival Sciences). Journal. Iran: Unversity of Isfahan.

[4]Davis, M. 2008. Tes EQ Anda (terjemahan). PT. Mitra Media.

[5] Haryanto. 2009. Pengertian Emosi. Tersedia: http://belajarpsikologi.com/pengertian -emosi/ [2 April 2014].

[6]Setyowati, A. 2010. Hubungan antara Kecerdasan Emosional dengan Resilensi pada Siswa Penghuni Rumah Damai. Jurnal. Semarang: UNDIP.

[7]Sugiyono. 2011. Metode Penelitian Pendidikan Pendekatan Kuantitaif, Kualitatif, dan R\&D.

[8]Riduwan. 2003. Dasar-Dasar Statistika. Bandung: Alfabeta.

[9]Nurfidyatun, 2009. Hubungan antara Kecerdasan Emosional dengan Prestasi Belajar pada Siswa Kelas II MTsN Tembalang Jombang. Skripsi. Malang : Universitas Islam Negeri Maulana Malik Ibrahim.

[10]Bahtiar, 2009. Hubungan kecerdasan emosional denganprestasi belajar siswa kela II SMA Negeri 2 Mataram.Jurnal.Tersedia:www.portalgaruda.org/downl oad_article.php?article=49353\&val. [3 Maret 2014].

[11]Saptono, 2011. Dimensi-dimensi Pendidikan Karakter. Salatiga : Erlangga.

[12]Supranto, J. 2008. Statistik Teori dan Aplikasi. Edisi Ketujuh. Jakarta : Erlangga.

[13]Erniati, 2014. Pengaruh Pola Asuh Orang Tua, Interaksi Teman Sebaya dan Kecerdasan Emosional Terhadap Hasil Belajar IPA pada Siswa Kelas VIII SMP Negeri Se-Kecamatan Mengwi. Jurnal. Singaraja : Universitas Pendidikan Ganesha.

[14]Soeharto, 2013. Faktor-faktor yang Berpengaruh terhadap Prestasi Belajar Teori Kejuruan Siswa SMK. Jurnal. Yogyakarta : Universitas Negeri Yogyakarta. 